\title{
リアリティ・モニタリング・エラー経験と視覚的イメージスタイル との関連性についての検討
}

\author{
$\bigcirc$ 中田英利子 ${ }^{1} \cdot$ 森田泰介 $^{2}$ \\ $\left({ }^{1}\right.$ 大谷大学・ ${ }^{2}$ 東京理科大学理学部第二部) \\ キーワード: リアリティ・モニタリング・エラー経験, 視覚的イメージスタイル, 質問紙法
}

\begin{abstract}
Relationship between reality monitoring error experience and individual differences in visual imagery style Eriko NAKATA ${ }^{1}$ and Taisuke MORITA ${ }^{2}$

( ${ }^{1}$ Otani University, ${ }^{2}$ Faculty of Science, Division 2, Tokyo University of Science)
\end{abstract}

Key Words: Reality monitoring error experience, Visual imagery style, Questionnaire method

\section{【目 的】}

実際に起こった出来事を知覚したことによって外的に獲得 された記憶と,自らの思考や想像によって内的に生成された 記憶とを区別する認知過程をリアリティ・モニタリング (Reality Monitoring: 以降, RM; Johnson, Hashtroudi, \& Lindsay, 1993; 中田, 2008)と呼ぶ。外的に獲得された記憶と内的に生成 された記憶とを取り違えてしまうことを, リアリティ・モニ タリング・エラー(以降， RM エラー)という。RM エラーに関 わる認知特性を検討するために, 中田・森田(2012)は RM 工 ラー経験と鮮明な視覚的イメージを体験できる能力との関連 性について検討した。その結果, 日常生活場面における RM エラー経験を測定できる質問紙(Reality Monitoring Error Experience Questionnaire: 以降, RMEEQ; 中田・森田, 2014)に おける視覚的な RM エラー得点と, 視覚イメージ鮮明性質問 紙(Vividness of Visual Imagery Questionnaire: 以降, VVIQ; Marks, 1973)の合計得点との間に有意な正の相関が認められ た。この結果は, 鮮明な視覚的イメージを体験できる能力が 高い者ほど, 内的に生成された記憶であっても知覚的詳細情 報が多く伴うため, RM エラーを犯しやすいと解釈された(e.g., Markham \& Hynes, 1993)。

神経心理学的研究, fMRI や PET を用いた脳機能研究, 行 動的指標を用いたワーキングメモリ研究により, 視覚イメー ジの処理を物体イメージ(object imagery)処理と空間イメージ (spatial imagery)処理とに分類できると報告されている(e.g., 川原・松岡, 2004)。前者は個々の物体の形や大きさ, 色, 明 るさについて鮮やかで解像度の高いイメージの想起に関わる 処理で, 後者は物体間の空間的関係図を描写したり, 思い浮 かべたイメージを変形したり操作することに関わる処理であ る。個人の視覚イメージ特性についても物体イメージ特性と 空間イメージ特性に分けて捉え直され(e.g., Kozhevnikov,

Kosslyn \& Shephard, 2005), 個人内でのこれらの処理の優先傾 向を測定できる質問紙も開発されている(e.g., Blajenkova, Kozhevnikov, \& Motes, 2006)。川原・松岡(2009)は日常生活に おける物体イメージと空間イメージの使用傾向を測定するこ とができる視覚的イメージスタイル質問紙(Visual Imagery Style Questionnaire: 以降, VISQ)を開発した。VISQ は物体イ メージ尺度 12 項目 (映像的なイメージを思い浮かべながら本 を読むことが多い等)と空間イメージ尺度 12 項目(知らないと ころに言っても東西南北をあまり間違えない等)の計 24 項目 から構成される。

しかしながら，個々の視覚イメージの使用や体験の傾向性 と RM エラーとの関連性についてのデータが十分蓄積されて いるとは言い難い。本研究では, 個人内での視覚的イメージ の使用傾向と RM エラー経験との関連性について調查的研究 を行う。物体イメージ特性が高い者ほど, 個々の物体につい て色鮮やかで解像度の高いイメージが想起できるため, 内的 に獲得された記憶であっても知覚的詳細情報が多く伴うなら ば，RM エラーを経験しやすいため, 物体イメージ得点と RMEEQ 得点との間に正の相関が認められると予測された。
空間イメージ特性が高い者ほど, 物体間の空間的配置等につ いて正確に想像できるとすれば, RM エラーはあまり経験さ れないため, 空間イメージ得点と RMEEQ 得点との間には負 の相関が認められると予測された。

\section{【方 法】}

調査対象者 大学生 78 名。このうち男性 45 名(年齢 $M=19$, $S D=1$, 範囲:18-23), 女性 33 名(年齢 $M=20, S D=2$, 範囲:18-25)。

調査用紙 RMEEQ は全 32 項目で, 評定值の合計得点から 日常生活場面での RMエラー経験(得意な分野の事柄について, 実際に見たこと・聞いたことがないのに，既に見たこと・聞 いたことがあると思いこんだことがある等)の頻度を測定す るものである。視覚的イメージの使用傾向を測定するために 川原・松岡(2009)により作成されたVISQを使用した。回答の 順番は常に RMEEQ, VISQ であった。聴覚イメージ鮮明性質 問紙(菱谷, 2005)も同時に実施したが，本研究とは無関係であ るため, 以後記述しない。

手続き 心理学の講義中に集団で調査を実施した。RMEEQ への回答は, 文章をよく読み, 各項目がふだんの自分にどの 程度該当するかについて 5 件法(4:非常によくある-0:まったく ない)によって求めた。VISQ への回答は, 文章 1-24 が普段の 自分に該当する程度について, 当てはまる程度を 5 件法 $(5: よ$ く当てはまる-1:全くあてはまらない)に置き換えて 1 つ文つ けて回答するよう求めた。回答終了後, 調査者が全ての調査 用紙を回収した。

\section{【結 果】}

記入漏れの者がいなかったため, 全てのデータを分析対象 とした。VISQの空間イメージスタイル得点と物体イメージス タイル得点との関連性について検討したところ, 両者の間に 有意な正の相関が認められた $(r=0.33, p<.01)$ 。そのため, VISQ の一方の尺度の影響を統制した場合の VISQ の尺度と，

RMEEQ との関連について検討するために, VISQ の片方の尺 度得点を制御変数に設定した偏相関分析を行った。空間イメ ージ尺度の影響を統制し, RM エラー経験と物体イメージ特 性との関連性について検討した結果，両者の間に有意な正の 相関が認められた $(r=0.33, p<.01)$ 。また, 物体イメージ尺度の 影響を統制し, RM エラー経験と空間イメージ特性との関連 性について検討した結果, 両者の間に有意な負の相関が認め られた $(r=-0.29, p<.01)$ 。

\section{【考 察】}

本研究の結果から,物体イメージの使用傾向が高い者ほど, 個々の物体の形や大きさ, 色, 明るさ等について鮮明で解像 度の高いイメージが体験されることにより, 内的に獲得され た記憶であっても知覚的詳細情報が多く伴うため, RM エラ 一を経験しやすいと考えられる。空間イメージの使用傾向が 高い者ほど, 物体の部品間の空間的関連性や配置, 物体の動 きや変化を正確に情報処理できるため, RM エラー経験が少 ないと考えられる。今後は, 空間イメージのような外的環境 についての正確な情報処理が， RM エラーを防止することが できる可能性について更なる検討が求められるだろう。 